\title{
Corporate Standards and Legal Rules ${ }^{\dagger}$
}

\author{
William L. Cary*
}

$\mathrm{T}$ $\mathrm{HE}$ interrelation of corporate standards and legal rules, of ethics-and law, is perhaps the preserve of philosophers, and the intrusion of a bureaucrat may be regarded as poaching. However, I am not writing on ethical standards as a theologian. Nor do I want to occupy the role of a Pollyanna, even though I firmly believe that a proper function of the Securities and Exchange Commission is to raise standards in the industry. I should like to focus upon the role of the counselor in business transactions. To what extent should he advise that standards-not yet law-nonetheless be observed? Lest you think I am trying to convert lawyers into philosophers, I would emphasize the practicality of advising clients on the basis of tomorrow's law. The man whose vision is limited to the scope of the West Reporter System in my opinion is not a valued counselor. I hope to be able to convey the wisdom in being sensitive to, and anticipating, public reactions that may crystallize into legal restraints.

Let us begin with definitions. The law-which we are all presumed to know-represents the standards presently imposed by a governmental or quasi-governmental authority. Ethical action, on the other hand, is that which is notivated by a self-imposed standard rather than compelled by law. The wise counselor will assess the need for ethical restraint because he views it as a potential legal restraint. One inight describe this as "becoming" law.

My principal discussion will relate to the conflict of interest problems of the managers of a corporation; that is, the duty of loyalty owed by management to the corporation. ${ }^{1}$ To my mind, the theory of complete disclosure is the principle which should underlie both legal rules and ethical standards in this area. It is the disclosure principle upon which a rational evolution of a theory of control over management must be premised. When I came to the SEC a year ago, I thought initially that the philosophy of disclosure had been fully depleted. Increasingly, however, I am convinced that in a pluralistic society-where, as in a business enterprise, so many

$\dagger$ This article is based upon a talk given as the Second Annual Walter Perry Jobnson Lecture on Law and Public Affairs, University of California School of Law, Berkeley, March 24, 1962. The author wishes to acknowledge the assistance of Arthur Fleischer, Jr., Executive Assistant to the Chairman.

* Chairman, Securities \& Exchange Commission.

1 See generally Baker \& CARY, Corporations 432-619 (3d ed. 1959) [hereinafter cited as BAKER \& CARY]; Kaplan, Conflict of Interest in Corporations, in CoNFERENCE on Conflict OF INTEREST 34 (U. Chi. L. School 1961). 
forces are operative-disclosure is the most realistic means of coping with the ever-present problem of conflicts of interest. In some instances our conduct is motivated by what we think is right, without regard to anything else. But perhaps equally as important, ethical behavior-and wise counselling-results from estimating the public reaction to a full knowledge of a planned course of conduct. The requirement of disclosure in certain instances, and its possibility always, is thus a most important regulatory force in our society. Disclosure is the foundation of reliance on self-regulatory approaches to conflict problems and is the clearest alternative to greater governmental or institutional intervention.

THE IAW: STATE AND FEDERAI

Disclosure is a concept of several facets. It may be viewed differently from the standpoint of state law and of federal developinent. Failure to disclose (coupled with fairness) is the key to state law treatment of conflict of interest problems. ${ }^{2}$ Essentially this represents a failure to notify the board of directors, as distinguished from a positive duty to inform the public. The law in this area has seen a shift from a rigid formalism, which imposed inflexible limitations on all insider transactions, to a rule of reason, which takes into account various factors in deciding on the propriety of a transaction. ${ }^{3}$ Modern doctrine recognizes that transactions by managers may be entirely beneficial to a corporation. Moreover, where in our economic system managers serve more than one corporation, affiliation between two companies, through common directorship or otherwise, should not alone bar their dealings.

Under state law, the conflict of interest problem is described in ternis of an undisclosed, adverse interest by a manager in transactions with his company. If it exists, the transaction may be voidable, because such an interest could subvert the obligation of complete loyalty which he owes. Furthermore, it makes no difference that the transaction was beneficial to the corporation at the time of consummation; the purpose of forbidding undisclosed interests is to eliminate inducements to wrongdoing and promote freedom of judgment, rather than provide for restitution of damages. The transaction itself might be framed differently-other alternatives

2 For analysis of state law, see 3 Fletcher, Private Corporations $\$ \$ 913-88$ (perm. ed. rev. repl. 1947); 1 HornsteIN, Corporation LaW aNd Practice $\S 439$ (1959).

3 Compare Mobile Land Improvement Co. v. Gass, 142 Ala. 520, 39 So. 229 (1905), with Cal. Corp. Code \$ 820. See Henn, Corporations 375 (1961); de Capriles, Fifteen Year Survey of Corporate Developments, 1944-1959, in Corporate Practice 10 (Roady \& Anderson ed. 1960). 
might be more fully explored-if interested persons were not participating. ${ }^{4}$ If, however, there is disclosure of an adverse interest, plus condonation by an independent body (either the board of directors or shareholders), the prohibitions against dealing may dissolve."

There are various limitations with respect to state law conflict of interest doctrine. In the first place, the doctrine may only apply to a "substantial" undisclosed interest-one that rnight reasonably be expected to affect judgment. ${ }^{6}$ Secondly, disclosure of an interest often need go no further than the board of directors. ${ }^{7}$ Finally, the fairness test may not be entirely satisfactory because there is a heavy burden to upset the judgment of directors even in a conflict situation. ${ }^{8}$

Whereas state law stresses the failure to disclose and the use of disclosure as a ratification device, federal law differs in putting emphasis on the positive aspects of disclosure and compelling disclosure to the public generally, as compared to a himited group. These points are illustrated by the two basic functions of disclosure under federal law. In the first place, the securities acts require information to be made available to the public generally as a basis for enlightened investment judgment. One cannot make reasonable investment decisions unless he is in possession of current data on a company's operations. Of course, a very vital asset of any company is its management. The securities acts and the rules of the Commission recognize this in compelling publication of various facts about management: its compensation, whether in the form of salary, stock options, or deferred compensation payments; its transactions with the company and in shares of the company; and its background. ${ }^{9}$ The dissemination of such facts permits stockholders, and the investing public generally, to draw their own conclusions about management.

A second basic function of disclosure under the federal acts is its operation as a restraint against overreaching by insiders. The theory here is that the requirement of publicizing insider dealings will of itself be a moderating influence. Justice Frankfurter, who counseled the drafters of the Securities Act of 1933, expressed this position well:

The existence of bonuses, of excessive commissions and salaries, of preferential lists and the like, may all be open secrets among the knowing,

4 For the classic statement, see Guth v. Loft, Inc., 23 Del. Ch. 255, 270, 5 A.2d 503, 510 (1939).

5 See Baker \& Cary 451-52.

6 See Wadmond, Conflicts of Business Interest, 17 Bus. Law. 48, 58 (1961).

7 See the statutes collected in BAKER \& CARY 440-42.

$8 I d$. at 469.

${ }^{9}$ See, e.g., Securities Act of 1933, schedule A(14), (22), (24), 48 Stat. 88 (1933), 15 U.S.C. \& 77aa (1958); Securities Exchange Act of 1934, § 12(b) (1) (D), 48 Stat. 892 (1934), 15 U.S.C. $\S 78 l$ (b) (1) (D) (1958); SEC Schedule 14A, item 7, 17 C.F.R. $\$ 240.14 a$ (Supp. 1962) (proxy rules). 
but the knowing are few. There is a shrinking quality to such transactions; to force knowledge of them into the open is largely to restrain their happening. Many practices safely pursued in private lose their justification in public. Thus social standards newly defined gradually establish themselves as new business habits. ${ }^{10}$

In other words, disclosure restrains because of sensitivity to public reaction, caution about response to the "dissident" shareholder, and the possibility of legal action. I firmly believe that disclosure does operate in this deterrent manner. It is illustrated by following the course of various registration statements in their journey through the registration process. Upon filing, a statement may disclose that insiders are getting seventy per cent of the company for five per cent of the cash. Ofttimes, in response to requests by the staff of the Commission that the benefits to insiders be fully and clearly spelled out, this percentage share may be substantially reduced. ${ }^{11}$

Of course, there are limitations on federal law. Disclosure is limited to particular corporations and events, e.g., sale of securities; whether a concern's securities are listed; whether the offering made is of a particular amount. ${ }^{12}$ This leaves many companies with a substantial number of public shareholders not subject to continuous reporting requirements. Moreover, even where disclosure is required, not all potential conflict situations are revealed. A continuing question arises as to what disclosures are desirable in this area. Are all transactions of managers material, except for really $d e$

${ }^{10}$ Frankfurter, Securities Act-Social Consequences, Fortune, Aug. 1933, p. 55.

11 For examples, see McCorRack, UNDERsTaNDING THe SECURITIES ACT AND THE SEC 302 (1948).

The Commission has frequently based enforcement action on the failure to disclose, or falsely disclosing, insider transactions or information about management. See, e.g., United States v. Pope, 187 F. Supp. 12 (S.D.N.Y. 1960) (criminal conviction of certain principals for failure to disclose, in financial reports to the Commission and in proxy soliciting material, certain material transactions of the issuer in which the principals had substantial interests); Faradyne Electronics Corp., SEC Securities Act Release No. 4469 (March 21, 1962) (stop-order proceeding based on, among other things, failure to disclose contenmplated lease of property from affiliates); Mutual Employees Trademart, Inc., SEC Securities Act Release No. 4478 (April 17, 1962) (suspension of regulation A exemption for failure to disclose insider transactions).

12 At present issuers having securities registered on a national securities exchange are required to file with the Commission monthly, semi-annual, and annual reports essentially detailing the material events which have occurred during the reporting period, including financial data, mergers, and transactions with insiders. Similar reports must be filed by other issuers, which have registered, under the Securities Act of 1933, securities of a class aggregating more than \$2 million. Securities Exchange Act of 1934, \$\$ 13, 15(d); 48 Stat. 894, 895 (1934), 15 U.S.C. $\$ \$ 78 \mathrm{~m}, 780$ (d) (1958). Efforts have been made on numerous occasions to extend the reporting requirements and to subject compamies whose securities are traded in the over-thecounter market to the proxy and insider trading sections of the 1934 act. The latter at present apply only to issuers whose securities are registered on an exchange. See 2 Loss, SEcurrties REGULATION 1149-51 (2d ed. 1961). This area is being re-examined in connection with the Commission's current Special Study of the Securities Markets. See Securities Exchange Act of 1934, § 19(d), 75 Stat. 465 (1934), 15 U.S.C. § 785(d) (Supp. III, 1962). 
minimus ones? In the present basic reporting forms of the Commission no interest need be disclosed unless both the interest and the transaction are material..$^{13}$

There are other exemptions that raise serious questions. For example, the manager might have a $\$ 900,000$ interest in $\$ 10$ million worth of sales to his company, but, because of the size of the company, no facts need be disclosed. It would certainly not be desirable to compel the reporting of trivia. But, if the necessity for disclosure is to be gauged by the materiality of information to the investor, can it not be argued that all management transactions with their company-except the most incidental-are material in that they at least partially convey the attitude of the management toward the use of their office? If management transactions are so frequent that their reporting becomes a burden, such a course of dealing would probably be of great interest to the shareholders.

\section{II}

\section{IILUSTRATIVE TRANSACTIONS}

Having seen the boundaries of the state and federal law-what do ethical standards suggest? The interplay between law and ethics todayand the demands imposed upon the wise counselor-are commonly seen in conflict of interest situations that are primarily tax motivated. With increasing frequency, insider dealings can undoubtedly be traced to attempts by executives to convert ordinary income into capital gains. These transactions raise basic questions. What sort of disclosure and to whom? What use can management properly make of its office? Do not ethical standards suggest managerial restraint? Let us examine some of these transactions.

\section{A. Sale of Goods to a Corporation}

In one publicized case, the president of a corporation was a substantial stockholder in two corporations which sold supplies to the company. Upon public disclosure of these facts, the president resigned. Let us assume that the product was of superior quality, and the price competitive. At a minimum, should not these transactions have been fully disclosed to the board of directors of the company to determine whether the transactions were competitive and the prices involved fair? Should not disclosure have been made to the stockholders? Finally, does the fact that the corporation did

13 Form S-1, item 20, para. 8 (form for registration of securities under Securities Act of 1933) ; SEC Schedule 14A, item 7(f) (para. 7), 17 C.F.R. \$ 240.14a (Supp. 1962) (proxy rules). Compare Item $2 \mathrm{~A}$ of Proposed Amendments to Form 8-K, SEC Securities Act Release No. 4474 (April 5, 1962). 
not learn of these events for a long time carry any lessons as to internal reporting systems? Certainly there has been a spate of counpany questionnaires as to insider dealings since that time.

\section{B. Sale or Purchase at Cost}

The previous category involved an ordinary commercial transaction where a director or other insider sold property to the corporation at a profit (reasonable or otherwise). This raises the immediate question of fairness. Another type of dealing-perliaps more subtle-involves situations in which the insider buys from, or sells property to, the corporation at cost. But there are distinct advantages to the insider because of lis tax position. In one well known case, a director, who was also president of the largest creditor of a corporation, bought certain properties and sold them at cost to the corporation. The director put $\$ 100,000$ of his money into the transaction and borrowed approximately $\$ 4$ million. The property was subsequently resold to the corporation at the director's cost plus his interest costs, the payments to be made by the corporation on a royalty basis. The benefit to the executive was that lie could deduct the interest payments from ordinary income, secure a capital gain on the sale, and might receive a depletion allowance on the product involved (against ordinary income). These tax differentials would have netted the executive a total tax benefit of approximately $\$ 400,000$ in four years on his $\$ 100,000$ investment. Upon disclosure of these facts, the executive resigned his office.

\section{Sale and Lease Back}

A similar transaction involves the purchase by an insider of real estate or other property from the corporation and its immediate lease back. The corporation gets the use of money for a particular period. The insider derives tax advantages because of the depreciation write-offs under the income tax laws. ${ }^{14}$

What does this type of transaction suggest? At a minimum, complete and full disclosure should be made of all the facts to the board of directors and to the stockholders, mcluding the terms of the transaction; the benefits and disadvantages to the company-spelled out clearly; and the tax advantages to the insider-in detail. I recognize that, from an accounting or financial point of view, these transactions may not be harmful to the corporation. But I would suggest this test: Are they positively to its advantage? Another test is: Absent interested participation, could another transaction have been to greater advantage?

14 See generally Cary, Corporate Financing Through the Sale and Lease-back of Property: Business, Tax, artd Policy Considerations, 62 HARv. L. REv. 1 (1948). 
I must acknowledge my reservations where the primary purpose of an arrangement seems to be to secure a tax advantage for the insider. If this is the primary motivation, or at least appears to be, should not the officer or director exercise extreme restraint? Is the use of the office of a director, and a president of the largest creditor of a corporation, to be devoted to such an arrangement? These are occasions, I would think, where the counsel might well emphasize the value of self-restraint in addition to describing the law's circumference. Again I repeat that sensitivity to public reaction is an essential ingredient of wise advice.

\section{Expense Accounts}

Executive expense accounts present problems somewhere in between so-called neutral transactions and profit sales by insiders. The great furor in this area has revolved around the tax propriety of particular deductions. ${ }^{15}$ From a tax point of view, the question is whether the executive is charging off as business expenses-or whether the company is charging off as business expenses-what may really be personal expenses. This characterization of the problem immediately brings up its corporate aspects. Certainly insiders, as well as outsiders, are entitled to reimbursement for proper business expenses. However, to the extent a member of the expense account aristocracy over-indulges himself, he may be taking additional compensation without appropriate accounting and disclosure. The trend of the tax laws is to compel disclosure to the company..$^{10}$ But is that where reporting of this information should end? In any case, the expense account problein requires particular individual restraint. No matter what internal systems a company may set up, it will be fundamentally a matter of conscience with an executive whether a particular expenditure is necessary for proper corporate purposes or whether it is excessive. Even this can in part be ameliorated through disclosure-by broad availability to the publicalthough I recognize certain practical limitations here. Under any circumstances, a responsible executive should entertain as if he had to make a public accounting. This would be a just dessert.

\section{III}

\section{TRANSACTIONS IN SHARES}

I would now like to turn to another aspect of the conflict of interest problem-trading in shares. Here the manager does not deal directly with

15 See Rothschild \& Sobernheim, Expense Accounts for Executives, 67 YaIE L.J. 1363 (1958) ; Hearings on H.R. 10650 Before the Senate Committee on Finance, 87th Cong., 2d Sess. 267 (1962) (Treasury Department Study on Entertainment Expenses).

10 Treas. Reg. \$ 1.162-17 (1958). 
the corporation, nor necessarily with its stockholders. This focuses attention on proper use of a manager's office: what restrictions should be placed on an officer or director with respect to trading in the shares of his company? Particularly, what responsibilities do insiders have when they secure non-public mformation about an event, such as a dividend cut or a merger, that is reasonably certain to affect the price of the stock? Under state and federal law disclosure is again the motif. ${ }^{17}$ Section 16(a) of the Exchange Act requires officers, directors and ten per cent stockholders of companies whose securities are listed on an exchange to report purchases and sales of the company's stock. ${ }^{18}$ Furthermore, both state and federal law-the latter more vigorously-have imposed restrictions on insiders with respect to trading.

What are the responsibilities of insiders with respect to securities transactions? Where an insider has possession of facts that are known to him by virtue of his status and that, if known generally, would tend materially to affect the price of the security, the law requires that the insider disclose these facts to those with whom he deals or forego the transaction. Here the law is now beginning to crystallize. It is a fraud on the other party to a security transaction not to speak if there is a duty to do so. This duty may arise: (1) because of a relationship to the corporation, such as that of an officer or director, and (2) by reason of the inherent unfairness involved where a person takes advantage of information knowing it is unavailable to those with whom he is dealing. ${ }^{19}$

A manager should receive corporate information not for his own personal emolument, but to assist the corporation in its operations. The use of inside information by a director or other manager to trade in shares is the securing of additional compensation in a covert faslion and should be condemned. (It further, of course, imfects the integrity of the market.) Since a director or manager is usually not in a position to discuss confidential information about his corporation, his alternative-and properly so-is to stay out of the market. In the recent case of Cady, Roberts $\mathcal{E} C o .{ }^{20}$ the Securities and Exchange Commission, for the first time, said that the duty of insider disclosure or-in the alternative- of abstinence applied in an exchange market and that it was a fraudulent practice to sell a security

17 See BAKER \& CARY 553-619.

1848 Stat. 896 (1934), 15 U.S.C. \$ 78p(a) (1958). Section 16(b) of this act provides for recovery by the company of any profits obtained by an "imsider" from the purchase and sale, or sale and purchase, of the company's securities within a six month period. 48 Stat. 896 (1934), 15 U.S.C. $\$ 78 p$ (b) (1958).

10 See Cady, Roberts \& Co., SEC Securities Exchange Act Release No. 6668 (Nov. 8, 1961), 71 Yare L.J. 736 (1962).

20 SEC Securities Exchange Act Release No. 6668 (Nov. 8, 1961). 
while in possession of inside information in a faceless transaction as well as face-to-face.

I should like to compare this viewpoint with that of the Massachusetts court in Goodwin v. Agassiz, ${ }^{21}$ decided prior to the enactment of the Exchange Act, involving a purchase by directors in an exchange transaction. The supreme judicial court there stated that:

Purchases and sales of stock dealt in on the stock exchange are commonly impersonal affairs. An honest director would be in a difficult situation if he could neither buy nor sell on the stock exchange shares of stock in his corporation without first seeking out the other actual ultimate party to the transaction and disclosing to him everything which a court or jury might later find that he then knew affecting the real or speculative value of such shares. Business of that nature is a inatter to be governed by practical rules. Fiduciary obligations of directors ought not to be made so onerous that men of experience and ability will be deterred from accepting such office. Law in its sanctions is not coextensive with morality. ${ }^{22}$

This statement was made in 1933. Is this the advice that counselors would give their clients today? It may conceivably liave been the temper of a particular court in 1933. After all, before the turn of the century a famous railroad buccaneer said, "Why buy the shares if we can buy the directors," a statement which would have undoubtedly shocked the Massachusetts court in Goodwin v. Agassiz.

But would any counsel reading the Goodwin case today advise his clients on the basis of the quoted view? Even this court said in a later paragraplı: "On the other hand, directors cannot rightly be allowed to indulge with impunity in practices which do violence to prevailing standards of upright businessmen." ${ }^{23}$ I would agree with the court that "law in its sanctions is not coextensive with morality." But I would suggest that the law of today embodies the morality of yesterday and should be anticipated. Business ought to be covered by practical rules of course. But is it impractical-and would it deter men of principle from accepting managerial office-if they liad to refrain from trading in securities when they lrad special inside information about the company concerned? The law now seems to say no, wlien it once appeared to say yes.

In this connection, let us consider a recent poll of businessmen conducted by the Harvard Business Review. ${ }^{24}$ The following question was asked: If you were a member of the board of directors and had knowledge of a merger of another company into your company and knew that the

21283 Mass. 358, 186 N.E. 659 (1933).

22 Id. at $362-63,186$ N.E. at 661 .

23 Id. at 363, 186 N.E. at 661.

24 Baumhart, How Ethical Are Businesmen, Harv. Bus. Rev., July-Aug. 1961, p. 6. 
price of the shares of the other company would appreciate in value when the information became public, would you purchase shares of the other company? Over forty-two per cent stated that they would buy the shares for themselves. In a question asking what the individual polled thought that the average executive would do, sixty-one per cent answered that the average executive would buy the stock.

This poll reveals several things. First of all, one tends to think of his sense of ethics as higher than the average man. Second, a surprising, and perhaps shocking, number of executives feel that it is perfectly reasonable conduct to use inside information for their personal benefit. Does the Commission's decision in the Cady, Roberts $\mathcal{E}$ Co. case serve as a reminder of their responsibilities? Finally and more importantly, what transactions would these executives effect if they knew that their stock purchases would be publicized and exposed to the public view? I suggest that the possibility of full disclosure of any purchases might lead to abstinence. If that is the case, would not the well-advised director act as if such disclosure would occur? This may not be law, but it is-I maintain-wise legal counsel.

All of the above examples suggest the necessity for counsel to measure not only the law's restraints but to gauge the public reaction to potential courses of conduct. Counsel should advise his chent to act as if all the facts of a particular transaction have been disclosed. Even though a transaction might be legal, if an adverse public reaction were anticipated, I would suggest that counsel should advise against the transaction because this adverse reaction might translate itself into a legal prohibition. If the disclosure test would lead counsel still to recommend the transaction even though it raised a question of propriety, I would further ask whether its disclosure would not be appropriate.

\section{IV}

\section{ETHICAL STANDARDS AND DISCLOSURE}

Observance of ethical standards as a matter of busmess wisdom has been referred to by Adolf Berle as the operation of "public consensus," the anticipation of public opinion. ${ }^{25}$ Berle describes this in part as the growth of the corporate conscience. ${ }^{26}$ It is possibly more appropriate to call it growth of management consciousness-an awareness of a developing public mandate that executives conform to high standards of conduct.

25 See Berie, Power Without Property 110 (1959).

20 Berde, The 20th Century Capitautst Revolution 113 (1954). It should be noted that Berle lays great stress on the power of the "public consensus"-the "body of general, unstated premises which bas come to be accepted"-as a check on management. 
What are the levels of management consciousness? What the manager thinks other managers should observe? Higher standards that he himself thinks he should observe? The highest standard that the general public reading about him would expect him to observe? (Regardless of what the reading public themselves do under the circumstances-an interesting contrast.)

The last-what the public thinks-is perhaps the most forceful restraint, as illustrated by a recent incident. Prior to June 30, 1960, only one out of ten large American corporations had issued general policy statements concerning conflicts of interest. By the middle of 1961, approximately minety per cent of the largest corporations in the country had promulgated more or less elaborate directives laying down explicit rules and regulations with respect to conflict of interest. About three quarters of these companies have called on their officers and directors for details of their financial affairs. ${ }^{27}$

What brought about this change in attitude? During this interval, the president of a large corporation resigned after public disclosure was made of his substantial transactions with the company. Although not legally compelled to establish conflict of interest procedures, management's decision to do so was perhaps a recognition of their practical - or "political," if you like-vulnerability in light of this incident. Management cannot well carry the burden of public censure. This incident illustrates management response to public opinion. But should not management and their counselors anticipate not only laws that may result from aroused public opinion, but events that will arouse that opinion? If management asks whether they may do a particular thing, the wise counselor may say: "It seems legally proper but would you like all of the details printed in the Wall Street Journal?" This wise counselor will be motivated not only by what he considers public response but hopefully by his personal behef as to what is proper. It is depressing to find the gradual ascent toward higher standards catalogued under the dusty heading "good public relations."

\section{V}

QUASI-PUBLIC CORPORATIONS: LIMITS UPON AND REASONS FOR DISCLOSURE

The law generally limits disclosure to particular events, such as the sale of securities; to particular companies, such as those whose securities are listed; or to particular persons, such as to the board of directors. Are there any justifications for these restrictions?

I should like to suggest reasons for compelling disclosure on a broad

27 Thanhouser, The Corporate Cornsel's Viewpoint, 17 Bus. LAw. 79 (1961). 
basis. First, should not any corporation in whose shares there is a public interest, i.e., which has a substantial number of stockholders, be required to disclose all material information concerning its financial affairs, including management transactions? This type of disclosure is necessary in order to have a sensitive and informed market. In order to evaluate a coinpany, we must have information about its manageinent.

Secondly, corporate managements themselves seem to suggest that the modern corporation has a duty to disclose everything to almost everybody. Quite frequently we may read the following in a company annual report:

$[\mathrm{N}]$ o commercial organization, particularly one of [our] size, can exist without creating certain social influences and, thereby, acquiring responsibilities beyond those of a purely business nature. These responsibilities will certainly grow in the future, as [our] normal growth continues ...

In addition, [a corporation] ... has civic responsibilities to the various communities where its affiliates operate, financial responsibilities to the educational institutions from which it draws many of its key employees, and-under many categories-responsibilities to government.

If the company really believes, and says, that it has a responsibility to these numerous groups, must it not at least account to these groups by full disclosure?

Another reason for disclosure is the continuing and imcreasing relationships of many corporations with the government (both federal and local). Does not this trend tend to give these corporations a quasi-public character? What is the significance of that character?

A significant percentage of corporations presently offering their securities to the public for the first time are dependent entirely on government contracts. In many corporations some work is performed for the government, e.g., there may be a sale of goods to the government for stockpiling or other purposes. Many corporations are financed by government loans or financed by companies which have received government financing and special tax advantages, such as small business investment companies.

I would suggest that these government contacts impose on management most serious responsibihties. These contacts with the agencies of the public are perhaps a strong reason for disclosure to the public. They further suggest the need for management voluntarily to pursue higher standards or be confronted with a congressional investigation and subsequent demand to do so.

In this connection, I should like to point to a recent Presidential memorandum on conflict of interest problems of government consultants. ${ }^{28}$ This memorandum has particular applicability to scientists who serve as 
consultants to the government but also maintain positions in private industry. It lays heavy stress on disclosure as a control device. For example, if the consultant-on behalf of his private interests-negotiates with the government agency for which he consults, he should do so only with the knowledge and approval of a responsible government official. Moreover, disclosure of the financial interests of the adviser must be made to the agency. Finally, the memorandum speaks strongly of the impropriety of the adviser using information derived from his government service for his personal benefit. One might analyze this directive as regulation by the government of the business conduct of persons who have an intimate contact with government operations. To the extent that corporations have such intimate contacts and do not adopt proper standards, will Congress feel compelled to introduce further regulations ${ }^{29}$ All of the aforementioned factors lead me to the conclusion that disclosure should not only be broadened and made more pervasive in the corporate system, but that the principle should be strongly applied to other fields, such as labor-management relations.

\section{CONCLUSION}

If disclosure is made on a universal basis, does it follow that standards of conduct will be raised? Not necessarily. But disclosure has been, and will be, an effective restraining force. Of course, disclosure is not the same as control. ${ }^{30} \mathrm{An}$ executive may still pay himself what could be regarded as an unreasonable salary, disclose it and feel immune from attack by stockholders. However, we still have institutional controls and judges to serve as arbiters of unreasonable management behavior. I see no need for extensive regulation of conflicts of interest-of the type involved in the Investment Company Act ${ }^{31}$-for all corporations.

The foregoing discussion points to the need for internally imposed restraints-a refined sense of ethics on the part of management. It is the role of wise counselors to assist in the development of refined standards and to point out to the managers, as they themselves are so fond of saying, that good ethics are not only good business in the long run, but also the overture to law in an evolving society.

29 Compare a recent Congressional investigation of potential confict of interest problems involving non-profit research corporations serving the Department of Defense. Although operating as research agencies of the government, these corporations have a private status and are not subject to the federal confiict of interest laws and regulations. See N.Y. Times, Feb. 13, 1962, p. 1 , col. 1 .

30 Cf. Manning, Book Review, 67 Yare L.J. 1477 (1958).

31 Investment Company Act of 1940, 54 Stat. 789, as amended, 15 U.S.C. $\$ \S 80 a-1$ to -52 (1958). 